Article

\title{
Separation of Acetate Produced from C1 Gas Fermentation Using an Electrodialysis-Based Bioelectrochemical System
}

\author{
Jiyun Baek, Changman Kim, Young Eun Song, Hyeon Sung Im, Mutyala Sakuntala \\ and Jung Rae Kim *(1) \\ School of Chemical and Biomolecular Engineering, Pusan National University, 63 Busandeahak-ro, \\ Geumjeong-Gu, Busan 46241, Korea; bjyjupiter@naver.com (J.B.); aslongas77@naver.com (C.K.); \\ duddms37@naver.com (Y.E.S.); gj9338@naver.com (H.S.I.); sakuntala1819@gmail.com (M.S.) \\ * Correspondence: j.kim@pusan.ac.kr; Tel: +82-1-510-2393; Fax: +82-51-510-3943
}

Received: 1 September 2018; Accepted: 7 October 2018; Published: 16 October 2018

\begin{abstract}
The conversion of $\mathrm{C} 1$ gas feedstock, such as carbon monoxide (CO), to useful platform chemicals has attracted considerable interest in industrial biotechnology. One conversion method is electrode-based electron transfer to microorganisms using bioelectrochemical systems (BESs). In this BES system, acetate is the predominant component of various volatile fatty acids (VFAs). To appropriately separate and concentrate the acetate produced, a BES-type electrodialysis cell with an anion exchange membrane was constructed and evaluated under various operational conditions, such as applied external current, acetate concentration, and $\mathrm{pH}$. A high acetate flux of $23.9 \mathrm{mmol} / \mathrm{m}^{2} \cdot \mathrm{h}$ was observed under a $-15 \mathrm{~mA}$ current in an electrodialysis-based bioelectrochemical system. In addition, the initial acetate concentration affected the separation efficiency and transportation rate. The maximum flux appeared at $48.6 \mathrm{mmol} / \mathrm{m}^{2} \cdot \mathrm{h}$ when the acetate concentration was $100 \mathrm{mM}$, whereas the effects of the initial $\mathrm{pH}$ of the anolyte were negligible. The acetate flux was $14.9 \mathrm{mmol} / \mathrm{m}^{2} \cdot \mathrm{h}$ when actual fermentation broth from BES-based CO fermentation was used as a catholyte. A comparison of the synthetic broth with the actual fermentation broth suggests that unknown substances and metabolites produced from the previous bioconversion process interfere with electrodialysis. These results provide information on the optimal conditions for the separation of VFAs produced by $\mathrm{C} 1$ gas fermentation through electrodialysis and a combination of a BES and electrodialysis.
\end{abstract}

Keywords: electrodialysis; bioelectrochemical system; microbial fuel cell; $\mathrm{C} 1$ gas; carbon monoxide; acetate

\section{Introduction}

The biological conversion of industrial waste gases containing carbon dioxide and carbon monoxide are being highlighted to reduce the emissions of greenhouse gases and simultaneously produce the building blocks of fuel and more useful commodity chemicals [1,2]. Among them, CO, which is toxic and recalcitrant to the environment, accounts for 50 to $70 \%$ of the effluent gas from steel factories. Hence, appropriate treatment technologies are anticipated. Recently, Im et al. (2018) reported that a bioelectrochemical system (BES) could compensate for the limitation of natural biological CO conversion and enhance the production of volatile fatty acids [3]. The applied potential of the BES supplies reducing power for autotrophic microorganisms and improves the yield of $\mathrm{C} 1$ gas conversion and cell growth [4-8].

The metabolites produced from BES-based C1 fermentation may contain acetate as well as various volatile fatty acids (VFAs) and alcohols $[9,10]$. Therefore, additional separation processes are needed to 
isolate and/or concentrate acetate from fermentation broth. In a conventional study, the separation of ionic metabolites was carried out using chemical and physical methods, such as acidification, ion-exchange, crystallization, and adsorption. On the other hand, these attempts may need to be moderated with the recent trends of environmentally and economically sustainable research and development [11,12]. For example, in the case of acidification or ion exchange, considerable amounts of acid and alkali are consumed during the operation, which is problematic. Regarding crystallization or adsorption, additional purification and chemical waste discharge have been a concern.

Electrodialysis (ED) is a technology to separate and enrich target substances by transferring the ionic forms through a selectively transmissible ion exchange membrane under an electrochemically induced oxidation/reduction reaction [11]. The separation of fermentation metabolites by electrodialysis was proposed to prevent the inhibition of lactic acid [13]. Im et al. reported that BES-based C1 gas conversion produced up to $8.4 \mathrm{~g} / \mathrm{L}$ of acetate, which is an industrially useful intermediate chemical and a source for further biosynthesis. Recently, many research groups have attempted to separate acetate from a range of wastewater or microbial fermentation broths [14,15]. In a normal fermentation broth, the anionic form of acetate is the dominant species rather than acetic acid because the culture condition is generally near neutral $\mathrm{pH}$. Therefore, acetate species can be separated using the ion exchange membrane of an electrodialysis cell. In electrodialysis, the $\mathrm{H}^{+} / \mathrm{OH}^{-}$ ion can be supplied continuously by electrochemical control in electrodialysis, and this can provide a driving force to separate various metabolites from the fermentation broth without the need for additional chemical reagents, such as salts. Moreover, it is capable of separating and concentrating high purity substances efficiently compared to other methods, enabling applications in a wide range of industrial processes, including food and biofuel production [16,17]. In particular, there have been many applications of electrodialysis in bioelectrochemical systems [18-20]. For example, ethyl acetate was produced through biphasic esterification, and acetic acid was separated from the fermentation broth by electrodialysis [21]. In addition, acetic acid, which was produced from carbon dioxide in a three-chamber bioelectrochemical system, was separated by electrodialysis with yields of up to $13.5 \mathrm{~g} / \mathrm{L}$ over a 43 day period [5].

The system configuration of BES and electrodialysis have some similarity in terms of using an ion exchange membrane (or separator) and electrical input (or output) to (or from) the reactor. Thus, electrodialysis allows the direct production and isolation of the target metabolites from $\mathrm{C} 1$ gas fermentation. On the other hand, the most important and problematic issue of separation by electrodialysis is membrane fouling [22]. In the sludge, wastewater or fermentation broth, there are not only secondary metabolic products, but also unused growth media components and a large number of cells [23]. These undesirable substances or microbial cells attach to the surface of the membrane and/or block the functional group of the ion exchange membrane during the electrodialysis process, eventually resulting in a decrease in separation efficiency [24]. To solve these problems, pretreating the fermentation broth before introduction to electrodialysis or various modification methods of the ion exchange membrane have been suggested $[23,25,26]$.

This study examined the operational parameters in electrodialysis to separate acetate, which is applicable to $\mathrm{C} 1$ gas fermentation (Figure 1). The optimal conditions in the synthetic broth were investigated and applied to the fermentation broth. The efficiency and flux of acetate separation were compared in an actual fermentation broth and synthetic solution. The aim of this study was to assess the potential of a combination of electrodialysis with BES-based C1 gas fermentation. 


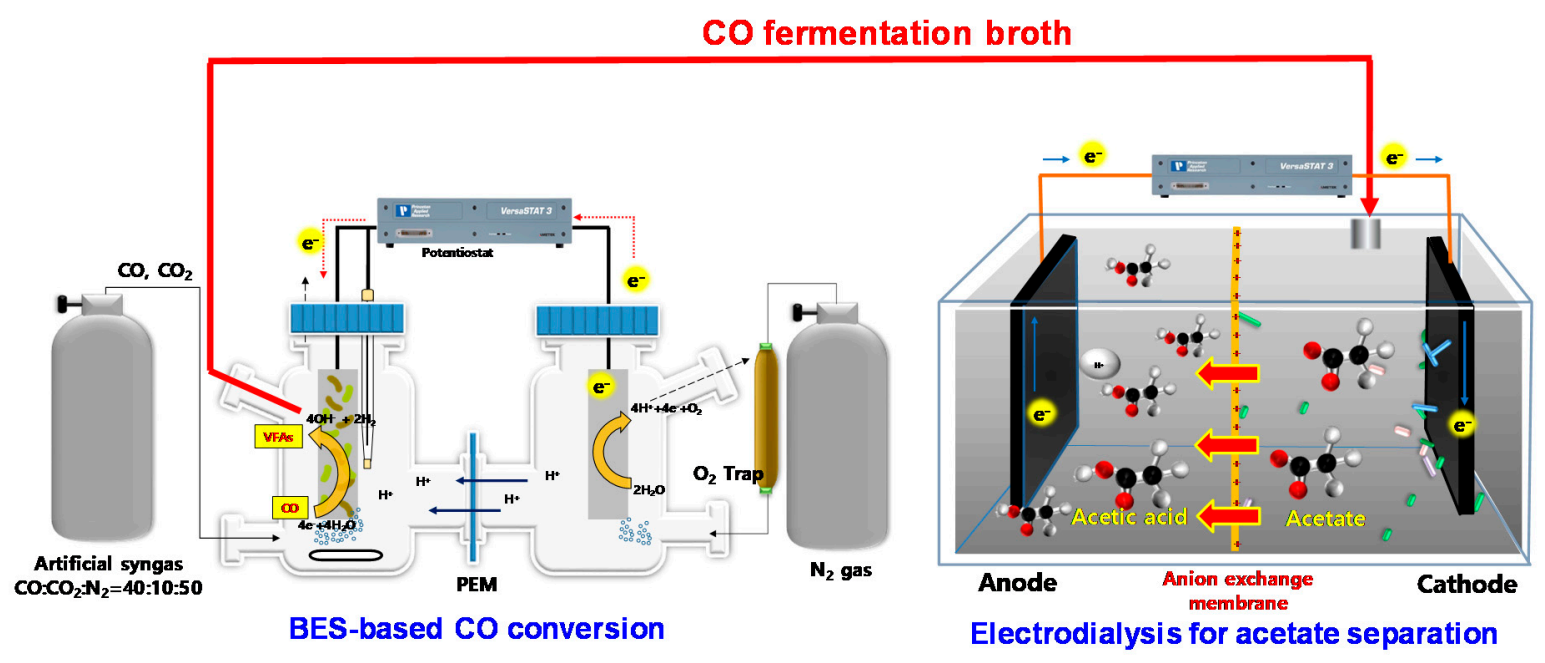

Figure 1. Separation and concentration of acetate from CO fermentation broth by electrodialysis cell. BES: Bioelectrochemical system.

\section{Materials and Methods}

\subsection{Configuration of Bioelectrochemical System and Electrodialysis Reactor}

An H-type BES reactor was used, as described previously [3,4]. Two media bottles $(310 \mathrm{~mL}$ capacity) were joined with a glass tube and a proton exchange membrane (Nafion 117; Dupont, Wilmington, DE, USA) and held with a clamp [27]. A $4 \mathrm{~cm} \times 5 \mathrm{~cm}$ piece of graphite felt (Cera Materials, Port Jervis, NY, USA) was implemented as the cathode electrode. Graphite granules ( $40 \mathrm{~g}$ ) were added to the anode chamber, and $5 \mathrm{~cm}$ of a graphite rod connected with titanium wire was used as the current collector from the graphite granules. The cathode potential $(-1.1 \mathrm{~V} \mathrm{vs.} \mathrm{Ag} / \mathrm{AgCl})$ was applied continuously through a multi-channel potentiostat (WMPG1000K8, Won-A tech, Seoul, Korea) during the experiment to support the BES-based biological CO conversion. A feed gas $\left(\mathrm{N}_{2}: \mathrm{CO}: \mathrm{CO}_{2}=50: 40: 10\right)$ was continuously provided into the cathode chamber at a flow rate of $10 \mathrm{~mL} / \mathrm{min}$. All experimental conditions performed were in accordance with the research reported by Im et al. [3].

The electrodialysis (ED) reactor used in this experiment consisted of an acrylic anode and cathode chamber; each chamber had a working volume of $73.5 \mathrm{~mL}\left(7 \times 7 \times 1.5 \mathrm{~cm}^{3}\right)$ (See Figure S1). Both electrodes were made of carbon paper (surface area of $42.25 \mathrm{~cm}^{2}, 120-\mathrm{TGP}-\mathrm{H}-120$, Toray, Japan), and connected to a circuit via a carbon fiber $(20 \mathrm{~cm})$. An anion exchange membrane $\left(49 \mathrm{~cm}^{2}\right.$, FKB-PK-130, Fumasep, Bietigheim-Bissingen, Germany) was used as the ion exchange membrane for the cell, and it was rinsed with a $0.5 \mathrm{M} \mathrm{NaCl}$ solution for $24 \mathrm{~h}$ prior to use. A potentiostat (WMPG1000, WonA Tech, Korea) in galvanostatic mode was used to apply a current to the reactor. To examine acetate separation from a realistic fermentation broth, both BES and ED were connected, as shown in Figure 1. In some cases, centrifuged fermentation broth, as described in Section 2.2, was introduced into the electrodialysis cell to examine the effects of particulates and cells in the media.

\subsection{Composition of Electrolyte}

Two types of catholytes were used to examine acetate transportation across the ion exchange membrane: synthetic broth and fermentation broth. The synthetic broth contained a $\mathrm{CO} / \mathrm{CO}_{2}$ fermentation medium, which was composed of the following (per liter): $1.5 \mathrm{~g} \mathrm{KH}_{2} \mathrm{PO}_{4}, 2.9 \mathrm{~g} \mathrm{~K}_{2} \mathrm{HPO}_{4}$, $2.0 \mathrm{~g} \mathrm{NaHCO}_{3}, 0.5 \mathrm{~g} \mathrm{NH}_{4} \mathrm{Cl}, 0.09 \mathrm{~g} \mathrm{MgCl} \cdot 6 \mathrm{H}_{2} \mathrm{O}, 0.0225 \mathrm{~g} \mathrm{CaCl}_{2} \cdot 2 \mathrm{H}_{2} \mathrm{O}$, and 0.5 g yeast extract. Sodium acetate (20 $\mathrm{mM}$ to $100 \mathrm{mM}$ for each reaction condition) was added to the catholyte to examine transportation through the membrane. The fermentation medium was made by slightly modifying the synthetic broth by also adding $2.11 \mathrm{~g}$ of sodium-2 bromoethanesulfonate as a methanogene inhibitor, $2 \mathrm{ml}$ of Pfennig's trace element solution, and $5 \mathrm{~mL}$ of a vitamin solution [3]. The $\mathrm{pH}$ was adjusted to 6.0 with $1 \mathrm{M} \mathrm{H}_{2} \mathrm{SO}_{4}$ and $1 \mathrm{M} \mathrm{NaOH}$. In some experiments, centrifugation was 
conducted at $7500 \mathrm{RPM}$ and $15 \mathrm{~min}$ to remove the cells and precipitates produced from former fermentation. Streptomycin $(20 \mu \mathrm{g} / \mathrm{mL})$ was added as an antibiotic to prevent acetate consumption due to contamination. The anode electrolyte consisted of the following ingredients (per liter): $0.8 \mathrm{~g}$ $\mathrm{K}_{2} \mathrm{HPO}_{4}, 1.0 \mathrm{~g} \mathrm{NH}_{4} \mathrm{Cl}, 2.0 \mathrm{~g} \mathrm{KCl}, 0.15 \mathrm{~g} \mathrm{CaCl}_{2} \cdot 2 \mathrm{H}_{2} \mathrm{O}, 2.4 \mathrm{~g} \mathrm{MgCl} \cdot 6 \mathrm{H}_{2} \mathrm{O}, 4.8 \mathrm{~g} \mathrm{NaCl}$, and $10.08 \mathrm{~g}$ $\mathrm{NaHCO}_{3}[5]$.

\subsection{Operation of Electrodialysis Reactor}

The cathode and anode electrodes were set as the working and counter electrodes, respectively. The current applied to the cathode ranged from 0 to $-15 \mathrm{~mA}$ using a galvanostatic method. The electrodialysis cells were located in the incubator at $25 \pm 1{ }^{\circ} \mathrm{C}$ and gently shaken at $30 \mathrm{rpm}$.

\subsection{Analyses}

A liquid sample $(<300 \mu \mathrm{L})$ was taken from each chamber periodically. The liquid samples were filtered through a $0.2 \mu \mathrm{m}$ syringe filter, acidified by $\mathrm{HCl}$ to prevent acetate volatilization, and stored in a freezer at $-80{ }^{\circ} \mathrm{C}$. The samples were analyzed by gas chromatography (GC, 7890B, Agilent Technologies, Santa Clara, CA, USA) and high-performance liquid chromatography (HPLC, HP 1100 series, Agilent Technologies, Santa Clara, CA, USA). The experiment was conducted in duplicate, and the analyses were carried out in duplicate. The initial and final $\mathrm{pH}$ were measured using a $\mathrm{pH}$ meter (Orion $420 \mathrm{~A}+$, Thermo Orion, USA). The current efficiency $\left(\eta_{A}\right)$ was estimated using the following equation:

$$
\eta_{A}=\frac{\Delta N_{A}}{i A \Delta t / F}
$$

where $\Delta N_{A}$ is the change in the molarity of acetate, $i$ is the current density, $A$ is the membrane area, $F$ is the faraday constant $(96485 \mathrm{C} / \mathrm{mol}=26.8 \mathrm{Ah} / \mathrm{mol})$, and $\Delta t$ is the interval of time [28].

The flux $\left(J_{A}\right)$ of acetate from the cathode to anode chamber was calculated using the following equation:

$$
J_{A}=\frac{\Delta m A}{A \Delta t}
$$

where $\Delta m$ is the amount of acetate transported from the cathode to the anode chamber, $A$ is the membrane area, and $\Delta t$ is the interval of time.

\section{Results and Discussion}

\subsection{Different Applied Current on Acetate Transportation in BES}

Acetate transport across the ion exchange membrane is affected by the applied potential and current in microbial fuel cells $[5,11,29,30]$. Therefore, the changes in acetate concentration in both the anode and cathode chambers were examined while various currents ( -5 to $-15 \mathrm{~mA}$ ) were applied to the cell (Figure 2). In the absence of an applied current, the final acetate concentration of $9.17 \mathrm{mM}$ was transported to the anode chamber during $16 \mathrm{~h}$ of operation, indicating that acetate had diffused to the anode due to the concentration gradient. On the other hand, acetate transport was increased to $12.55 \mathrm{mM}$ when a current was applied across the electrodes $(-5 \mathrm{~mA})$. Under $-15 \mathrm{~mA}$ application, $24.98 \mathrm{mM}$ of acetate was transported to the anode chamber. An externally applied current can drive the electrochemical reaction and actively move acetate anions against the concentration gradient between the anode and cathode chambers (Figure 2B-D) over $16 \mathrm{~h}$, whereas the acetate only diffused naturally in the control (i.e., under the absence of an applied current) (Figure 2A).

The amount of acetate transportation increased with increasing current in BES. On the other hand, the estimated current efficiency on the applied potential decreased at a higher current (Table 1). The current efficiency estimated by Equation (1) was higher $(54.4 \pm 0.2 \%)$ under a lower applied current $(-5 \mathrm{~mA})$, whereas it decreased at a higher current $(36.1 \pm 1.2 \%$ at $-15 \mathrm{~mA})$ (Table 1$)$. On the other hand, the acetate flux across the membrane was $23.9 \pm 0.8 \mathrm{mmol} / \mathrm{m}^{2} \cdot \mathrm{h}$ at $-15 \mathrm{~mA}$, whereas it 
decreased at a lower applied current $\left(8.8 \pm 0.4 \mathrm{mmol} / \mathrm{m}^{2} \cdot \mathrm{h}\right.$ at $\left.-5 \mathrm{~mA}\right)$ (Table 1$)$. The driving force for acetate anion transportation by electrodialysis is lost under a higher current in electrodialysis. These results are consistent with the previous observation that the selectivity for ions at a low current density was higher than that at a high current density [31]. At a high current density, the current efficiency was reduced because the driving force was dissipated by the movement of other ions in addition to the target acetate, and resistance in the ion exchange membrane.

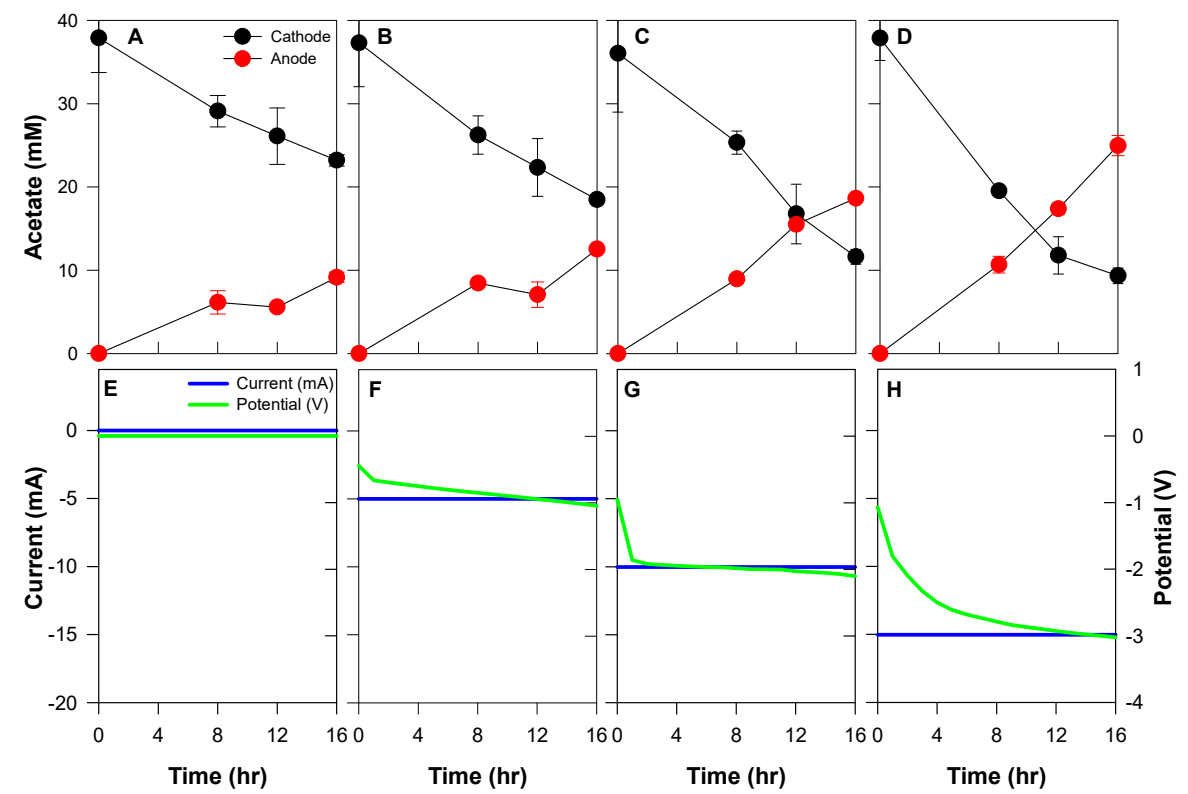

Figure 2. Acetate transfer from the cathode to the anode chamber under different current conditions. Without current application (A,E); $-5 \mathrm{~mA}(\mathbf{B}, \mathbf{F}) ;-10 \mathrm{~mA}(\mathbf{C}, \mathbf{G}) ;-15 \mathrm{~mA}(\mathbf{D}, \mathbf{H})$ during $16 \mathrm{~h}$ of operation.

Table 1. Entire migration amount of acetate in the cathode chamber, total applied current, current efficiency, and acetate flux.

\begin{tabular}{|c|c|c|c|c|c|}
\hline & Conditions & $\begin{array}{l}\text { Acetate Migration from } \\
\text { the Cathode }(\mathrm{mM})\end{array}$ & $\begin{array}{l}\text { Total Applied } \\
\text { Current (C) }\end{array}$ & $\begin{array}{c}\text { Current } \\
\text { Efficiency (\%) }\end{array}$ & $\begin{array}{l}\text { Acetate Flux } \\
\left(\mathrm{mmol} / \mathrm{m}^{2} \cdot \mathrm{h}\right)\end{array}$ \\
\hline \multirow{4}{*}{$\begin{array}{l}\text { Applied } \\
\text { current }\end{array}$} & $0 \mathrm{~mA}$ & $14.7 \pm 4.9$ & - & - & $8.8 \pm 0.4$ \\
\hline & $-5 \mathrm{~mA}$ & $18.8 \pm 5.2$ & 288.0 & $54.4 \pm 0.2$ & $12.0 \pm 0.0$ \\
\hline & $-10 \mathrm{~mA}$ & $24.4 \pm 7.9$ & 576.0 & $40.4 \pm 0.6$ & $17.8 \pm 0.3$ \\
\hline & $-15 \mathrm{~mA}$ & $28.5 \pm 3.6$ & 864.0 & $36.1 \pm 1.2$ & $23.9 \pm 0.8$ \\
\hline \multirow{4}{*}{$\begin{array}{c}\text { Acetate } \\
\text { concentration }\end{array}$} & $20 \mathrm{mM}$ & $16.3 \pm 2.1$ & \multirow{4}{*}{864.0} & $23.8 \pm 0.6$ & $15.8 \pm 0.4$ \\
\hline & $40 \mathrm{mM}$ & $30.1 \pm 4.5$ & & $40.2 \pm 1.2$ & $26.6 \pm 0.8$ \\
\hline & $80 \mathrm{mM}$ & $44.2 \pm 9.3$ & & $63.1 \pm 2.6$ & $41.8 \pm 1.7$ \\
\hline & $100 \mathrm{mM}$ & $55.9 \pm 11.3$ & & $73.4 \pm 4.6$ & $48.6 \pm 3.0$ \\
\hline \multirow{3}{*}{$\mathrm{pH}$ test } & 2.0 & $31.2 \pm 3.1$ & \multirow{3}{*}{864.0} & $43.4 \pm 2.8$ & $28.2 \pm 1.8$ \\
\hline & 4.0 & $30.6 \pm 6.3$ & & $42.8 \pm 3.4$ & $28.4 \pm 2.2$ \\
\hline & 6.0 & $28.9 \pm 3.9$ & & $40.1 \pm 4.1$ & $26.6 \pm 2.7$ \\
\hline \multirow{3}{*}{$\begin{array}{l}\text { Catholyte } \\
\text { composition }\end{array}$} & Synthetic & $25.3 \pm 0.9$ & \multirow{3}{*}{864.0} & $34.5 \pm 1.2$ & $22.9 \pm 0.8$ \\
\hline & $\begin{array}{l}\text { Fermented with } \\
\text { centrifuge }\end{array}$ & $11.4 \pm 1.2$ & & $22.5 \pm 1.5$ & $14.9 \pm 1.0$ \\
\hline & $\begin{array}{l}\text { Fermented without } \\
\text { centrifuge }\end{array}$ & $11.1 \pm 0.3$ & & $18.6 \pm 0.7$ & $12.3 \pm 0.4$ \\
\hline
\end{tabular}

\subsection{Effect of Different Acetate Concentration}

The effects of the initial acetate concentration (20 to $100 \mathrm{mM}$ ) on electrodialysis were investigated at an applied current of $-15 \mathrm{~mA}$ (Figure 3). The acetate flux was estimated to be $48.6 \pm 3.0 \mathrm{mmol} / \mathrm{m}^{2} \cdot \mathrm{h}$ at an initial acetate concentration of $100 \mathrm{mM}$, whereas it decreased proportionally to $15.8 \pm 0.4 \mathrm{mmol} / \mathrm{m}^{2}$.h with $20 \mathrm{mM}$ (Figure 3 and Table 1 ). At the highest acetate concentration $(100 \mathrm{mM})$, the current efficiency $(73.4 \%)$ was much higher than that a lower 
concentration ( $20 \mathrm{mM}$ vs. $23.8 \%$ ) (Table 1). These results suggest that a higher efficiency of acetate separation can be obtained at a higher acetate concentration. When no current was applied to the cell, separation was carried out by diffusion depending on the acetate concentration. This indicates that, in addition to the applied current, diffusion plays an important role in the transport of acetate [29]. Accordingly, a higher acetate concentration is required for optimal process efficiency, even though the performance of electrodialysis is also related to the reactor configuration. Im et al. examined the fermentation of acetate production from $\mathrm{CO}$ by electrosynthesis and revealed the productivity of acetate at a maximum of $8.4 \mathrm{~g} \mathrm{~L}^{-1}$ in a BES [3]. Therefore, electrodialysis-driven acetate separation around the maximum was examined in the electrodialysis cell. The separation of acetate at this point is expected to increase both the growth of microorganisms and the acetate productivity from CO conversion.

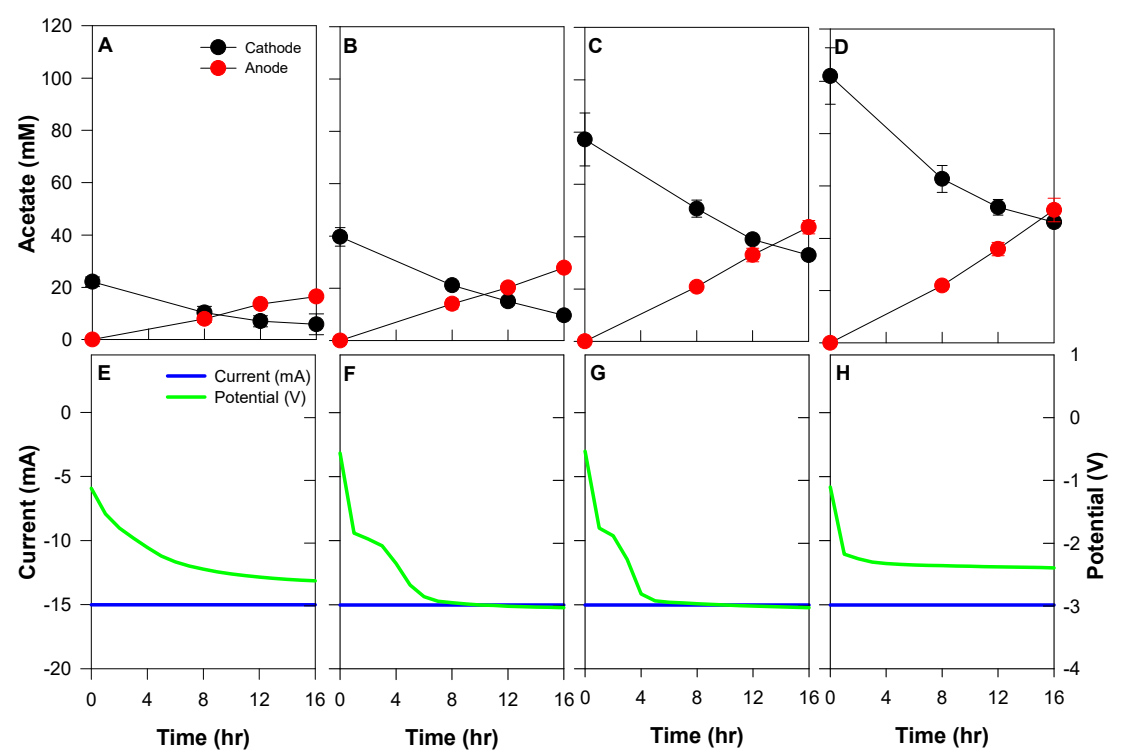

Figure 3. Change in acetate concentration by electrodialysis under various initial acetate concentrations in the cathode chamber, $20 \mathrm{mM}(\mathbf{A}, \mathbf{E}), 40 \mathrm{mM}(\mathbf{B}, \mathbf{F}), 80 \mathrm{mM}(\mathbf{C}, \mathbf{G})$, and $100 \mathrm{mM}(\mathbf{D}, \mathbf{H})$. The applied potential was fixed to $-15 \mathrm{~mA}$.

\subsection{Effect of Different Initial Anodic $p H$}

The $\mathrm{pH}$ of the anode chamber can also be an important factor for the efficient separation of acetate. The $\mathrm{pK}_{\mathrm{a}}$ of acetate is 4.76 . Hence, acetate exists mainly as an ionized form in the catholyte in the cathode chamber ( $\sim \mathrm{pH} 6.0)$, which is provided from the former BES reactor. To examine the effects of the anodic $\mathrm{pH}$ in electrodialysis, the anodic $\mathrm{pH}$ was adjusted from 2.0 to 6.0 while the cathodic $\mathrm{pH}$ was fixed to 6.0 because the $\mathrm{pH}$ from the effluent from the former $\mathrm{C} 1$ gas fermentation is approximately 6.0. As shown in Figure 4, the $\mathrm{pH}$ effect on acetate separation was negligible, and the current efficiencies were estimated to be approximately $40-43 \%$ under these $\mathrm{pH}$ conditions (Table 1 ). In electrodialysis cells, the following oxidation and reduction reactions take place in the anode (3) and cathode chamber (4);

$$
\begin{aligned}
& \mathrm{H}_{2} \mathrm{O} \rightarrow 2 \mathrm{H}^{+}+1 / 2 \mathrm{O}_{2}+2 \mathrm{e}^{-} \\
& 2 \mathrm{H}_{2} \mathrm{O}+2 \mathrm{e}^{-} \rightarrow 2 \mathrm{OH}^{-}+\mathrm{H}_{2}
\end{aligned}
$$

The $\mathrm{H}^{+}$produced by water electrolysis reaction (3) reduces the $\mathrm{pH}$ in the anode chamber continuously, which eventually approaches $\mathrm{pH} 2.0$, even if the initial $\mathrm{pH}$ of the anode chamber is higher than $\mathrm{pH}$ 2.0. The final $\mathrm{pH}$ of the anode chamber in the tested reactors was $\mathrm{pH} 1.9$ to 2.0, which converged from a varied initial pH 2.0 to 6.0. This suggests that proton transport from the anode to the cathode in the reverse direction of acetate anion species separation might be limited by the ion exchange membrane [32]. 


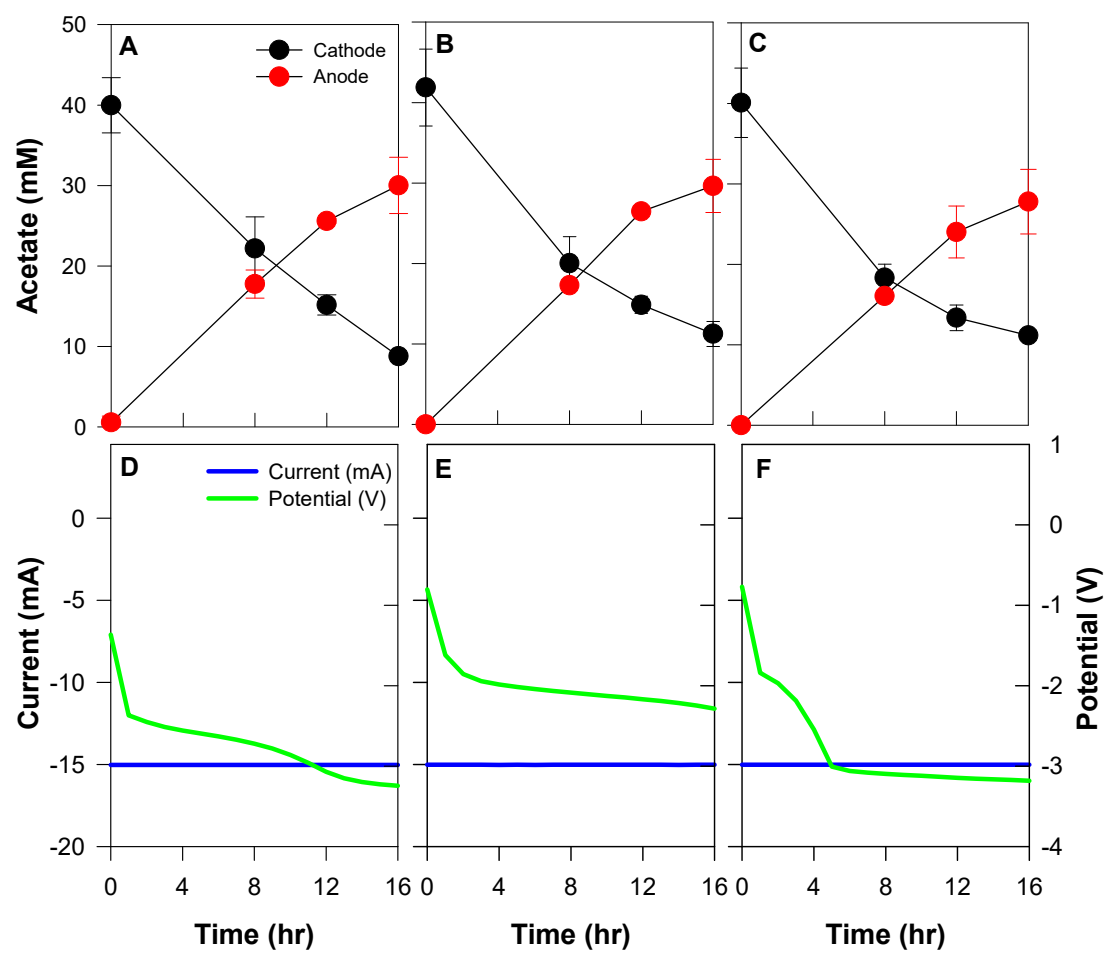

Figure 4. Changes in the acetate concentration by electrodialysis when the initial $\mathrm{pH}$ of the anode was varied. Initial anode pH 2.0 (A,D); pH 4.0 (B,E); pH 6.0 (C,F).

\subsection{Acetate Separation from the Actual Fermentation Broth}

The combination of acetate fermentation followed by electrodialysis-based acetate separation has been highlighted for biological C1 gas conversion. Based on the results of the above experiments, synthetic and fermentation broths containing acetate were compared for the separation of acetate in the electrodialysis cell. First, the cell and precipitate in the former fermentation broth were removed by centrifugation to exclude the effects of particulates in the broth. The final acetate concentrations with the fermentation and synthetic broth were $15.6 \mathrm{mM}$ and $23.9 \mathrm{mM}$, respectively (Figure 5). The results show that approximately $20 \%$ less acetate in the fermentation broth (i.e., effluent from the former electrosynthesis process) is transported to the anode chamber than the synthetic solution, even when the particulates were removed by centrifugation (Figure 5B). A similar but slightly lower acetate separation was obtained using a non-centrifuged fermentation broth (i.e., realistic cultivation broth from BES) $(13.30 \mathrm{mM})$ during the $16 \mathrm{~h}$ of operation (Figure $5 \mathrm{C})$. The other metabolites from $\mathrm{C} 1$ gas fermentation in BES, such as butyrate, propionate and iso-butyrate [3], hinder acetate separation significantly. As observed in the GC analysis results, unlike the synthetic medium, the fermentation broth contains various volatile fatty acids as well as acetate (Figure S2C,D). Among these metabolites, the longer chain VFAs, such as propionate, may pass through the membrane competitively with acetate, which might reduce the rate and efficiency of acetate separation. The GC results also show clearly that propionate has passed through the anion exchange membrane used in this study (Figure S2A,B). The competitive flux of these other anions is considered to be the cause of the relatively low current efficiency for acetate separation [21]. Because the former BES process was usually inoculated with inoculum, including sludge and isolated microorganisms, it contained a variety of particulates, colloidal and dissolved fractions, all of which can act as inhibitors and potential foulants. Microorganisms and soluble substances potentially cause membrane fouling, which decreases the electrodialysis performance [24,33,34]. Ghasemi et al. reported that the microorganisms attached to the membrane surface and the biofilm formation are major factors reducing the separation efficiency in the electrodialysis cell [22]. After the operation of the electrodialysis cell with a non-centrifuged fermentation broth, contamination by unknown substances was observed on 
the cathodic electrode, which was different from the synthetic and centrifuged fermentation broth (Figure S3D-F). These contaminants on the electrode and membrane may lower the current efficiency of acetate separation from the non-centrifuged fermentation broth in the electrodialysis cell.

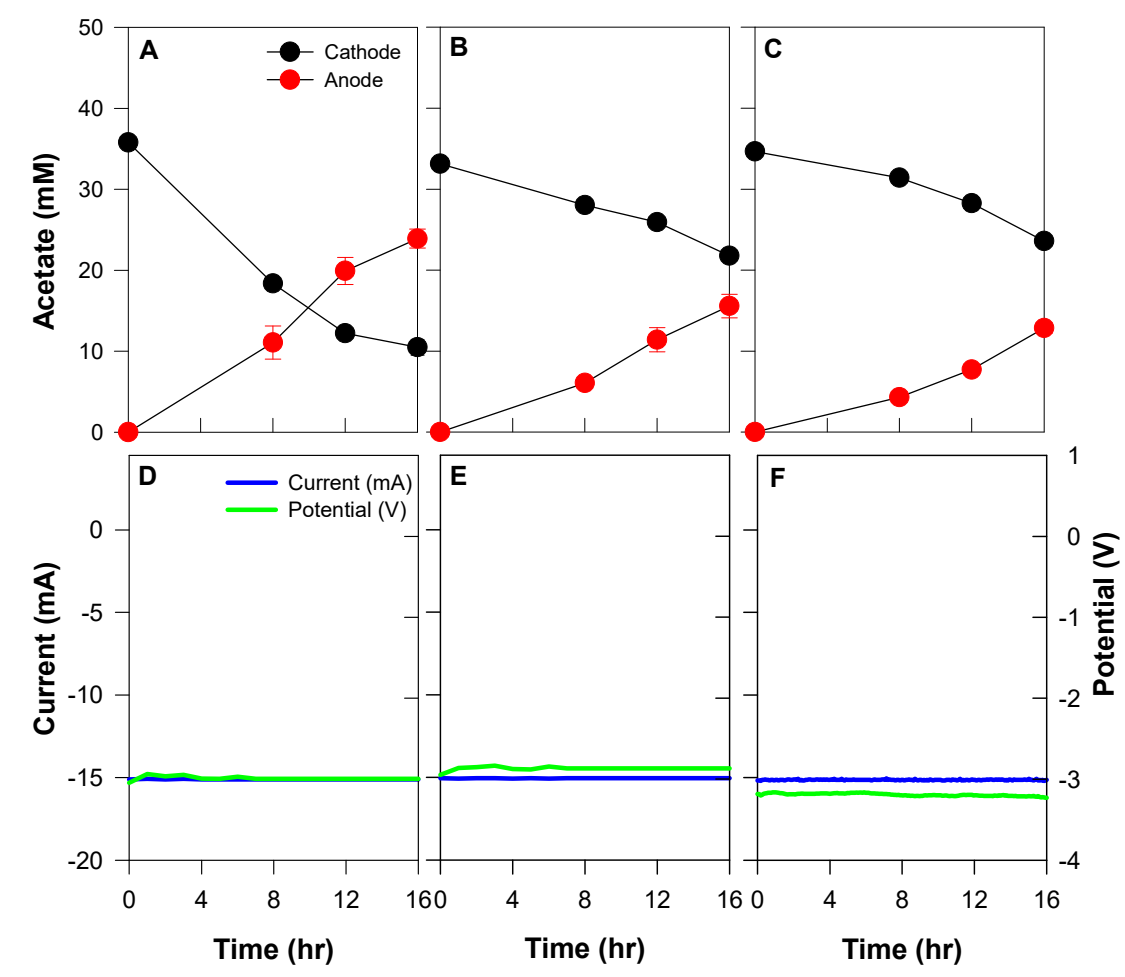

Figure 5. Comparison of acetate transportation in an electrodialysis cell with synthetic media containing acetate $(\mathbf{A}, \mathbf{D})$, and centrifuged $\mathrm{C} 1$ gas fermentation broth $(\mathbf{B}, \mathbf{E})$ and non-centrifuged $\mathrm{C} 1$ gas fermentation broth $(\mathbf{C}, \mathbf{F})$.

\section{Implication and Conclusions}

Acetate is one of the primary metabolites from $\mathrm{C} 1$ gas fermentation and is a useful intermediate chemical for further biosynthesis [35]. On the other hand, this fermentation broth contains a variety of components, such as ion species, VFAs, and microorganisms as well as acetate. Therefore, the development of appropriate acetate separation is essential, which accounts for between $30 \%$ and $40 \%$ of the total process cost [36]. In this respect, the production of acetate through BES and the separation of the produced acetate by electrodialysis may provide an appropriate platform for the in-situ processing and separation of acetate. Through these experiments, it was confirmed that a maximum acetate flux of $48.6 \pm 3.0 \mathrm{mmol} / \mathrm{m}^{2} \cdot \mathrm{h}$ can be achieved using the synthetic broth. When the $\mathrm{C} 1$ fermentation broth was applied, the flux was $14.9 \pm 1.0 \mathrm{mmol} / \mathrm{m}^{2} \cdot \mathrm{h}$, which was approximately half that of the synthetic broth $\left(22.9 \pm 0.8 \mathrm{mmol} / \mathrm{m}^{2} \cdot \mathrm{h}\right)$ under the same conditions, probably due to the various substances and other longer chain VFAs in the fermentation broth. The obtained separation rate and efficiency are comparable to the previous results of electrodialysis (Table 2).

There are still challenges that need to be overcome before this system can be applied to an actual industrial environment; several studies to solve these problems are underway. To solve the fouling of an ion-exchange membrane, some research groups have focused on modifying the membrane by a treatment with polymer compounds, such as poly (sodium 4-styrene sulfonate) (PSS)/poly(diallyldimethylammonium chloride) (PDADMAC) [34]. An ultra-low voltage customized DC-DC booster circuit [37] and maximum power point tracking (MPPT) [38] may provide an affordable voltage and current for self-sustained electrodialysis applications. Although further studies will be needed in the future, these results may provide a basis for techniques to isolate acetate from actual fermentation end products and culture broth from bioelectrochemical systems. 
Table 2. Volatile fatty acid separation using various ion exchange membranes and resins.

\begin{tabular}{|c|c|c|c|c|c|}
\hline Volatile Fatty Acids & Separated Acetate Titer & Separation Material \& Membrane & Applied Potential or Current & Current Efficiency (\%) & Reference \\
\hline Acetate & $1.21 \mathrm{~mol} / \mathrm{m}^{3}$ during 32 days & $\begin{array}{l}\text { Anion exchange membrane } \\
\left(1.77 \mathrm{~cm}^{2}, \text { AMI-7001) }\right.\end{array}$ & -800 mV (vs. SHE) & - & [39] \\
\hline Acetate & $0.379 \mathrm{~kg} / \mathrm{m}^{2} \cdot \mathrm{d}$ & $\begin{array}{l}\text { Anion exchange membrane } \\
\quad\left(64 \mathrm{~cm}^{2}, \mathrm{AM}-7001\right)\end{array}$ & $20 \mathrm{Am}^{-2}$ (vs. $\left.\mathrm{Ag} / \mathrm{AgCl}\right)$ & $36 \%$ (coulombic efficiency & {$[21]$} \\
\hline Acetate & $225 \mathrm{mM}$ during 43 days & $\begin{array}{c}\text { Anion exchange membrane } \\
\text { (Fumatech FAB) }\end{array}$ & $-50 \mathrm{~mA}$ (vs. SHE) & - & [5] \\
\hline Acetate & 100 mg/g (acetate sorption) & $\begin{array}{c}\text { Anion exchange resin } \\
\text { (35 g, Amberlite TM FPA53) }\end{array}$ & - & - & [40] \\
\hline Succinic acid & $15.7 \mathrm{~g} / \mathrm{dm}^{3}$ during $180 \mathrm{~min}$ & $\begin{array}{c}\text { EDMB stack: } 10 \text { Bipolar (PC 200bip), } \\
10 \text { Anion exchange (PC 200D), } \\
\text { Cation exchange(PC-SK), (207 cm² each) }\end{array}$ & $120 \mathrm{~A} / \mathrm{m}^{2}$ & $14.3 \%$ & {$[41]$} \\
\hline Lactic acid & $1.46 \mathrm{~mol} / \mathrm{L}$ during $15 \mathrm{~h}$ & $\begin{array}{l}\text { EDMB stack: Bipolar }\left(40 \mathrm{~cm}^{2}, \text { BMP-1), }\right. \\
\text { Anion exchange }\left(40 \mathrm{~cm}^{2}, \text { FAS-PET-130), }\right. \\
\text { Cation exchange }\left(40 \mathrm{~cm}^{2}, \mathrm{JCM}-\mathrm{II}-05\right)\end{array}$ & $40 \mathrm{~mA} / \mathrm{cm}^{2}$ & - & [42] \\
\hline Acetate & $12.3 \pm 0.4 \mathrm{mmol} / \mathrm{m}^{2} \cdot \mathrm{h}$ & $\begin{array}{l}\text { Anion exchange membrane } \\
\left(49 \mathrm{~cm}^{2}, \text { FKB-PK-130) }\right.\end{array}$ & $-15 \mathrm{~mA}$ & $18.6 \pm 0.7 \%$ & This study \\
\hline
\end{tabular}


Supplementary Materials: The following are available online at http:/ /www.mdpi.com/1996-1073/11/10/2770/s1. Figure S1. Schematic diagram of the electrodialysis reactor used in this study and a photograph. Figure S2. Comparison of propionate transfer through an anion exchange membrane. (A) Amount of propionate transferred to the anodic chamber, (B) applied current in the reactor for $16 \mathrm{~h},(\mathrm{C}) \mathrm{GC}$ analysis results of the fermentation broth, (D) GC analysis results of the synthetic medium. Figure S3. Membrane and cathodic electrode surface after the completion of electrodialysis for acetate separation. membrane (A) and cathodic electrode (D) from the cell using synthetic broth meida, respectively. $(B, E)$ from centrifuged fermentation broth, $(C, F)$ from non-centrifuged fermentation broth. Figure S4. Estimated current efficiency on different parameters tested. (A) Current efficiency of different currents from $-5 \mathrm{~mA}$ to $-20 \mathrm{~mA}$, (B) Effects of the initial acetate concentration, (C) Effects of different initial anodic $\mathrm{pH}$, (D) Effects of different catholytes with synthetic media (a), centrifuged fermentation broth (b) and non-centrifuged fermentation broth (c).

Author Contributions: Investigation and writing original draft, J.B., C.K.; Investigation, Y.E.S.; Methodology, H.S.I. and M.S.; Supervision, J.R.K.

Funding: This study was supported by the C1 Gas Refinery Program (NRF-2018M3D3A1A01055756) through the National Research Foundation of Korea (NRF) funded by the Ministry of Science, ICT \& Future Planning, Korea.

Conflicts of Interest: The authors declare no conflict of interest.

\section{References}

1. Ali, J.; Sohail, A.; Wang, L.; Haider, M.R.; Mulk, S.; Pan, G. Electro-microbiology as a promising approach towards renewable energy and environmental sustainability. Energies 2018, 11, 1822. [CrossRef]

2. Rabaey, K.; Rozendal, R.A. Microbial electrosynthesis-Revisiting the electrical route for microbial production. Nat. Rev. Microb. 2010, 8, 706. [CrossRef] [PubMed]

3. Im, C.H.; Kim, C.; Song, Y.E.; Oh, S.-E.; Jeon, B.-H.; Kim, J.R. Electrochemically enhanced microbial CO conversion to volatile fatty acids using neutral red as an electron mediator. Chemosphere 2018, 191, 166-173. [CrossRef] [PubMed]

4. Im, C.H.; Song, Y.E.; Jeon, B.-H.; Kim, J.R. Biologically activated graphite fiber electrode for autotrophic acetate production from $\mathrm{CO}_{2}$ in a bioelectrochemical system. Carbon Lett. 2016, 20, 76-80. [CrossRef]

5. Gildemyn, S.; Verbeeck, K.; Slabbinck, R.; Andersen, S.J.; Prévoteau, A.; Rabaey, K. Integrated production, extraction, and concentration of acetic acid from $\mathrm{CO}_{2}$ through microbial electrosynthesis. Environ. Sci. Technol. Lett. 2015, 2, 325-328. [CrossRef]

6. Batlle-Vilanova, P.; Puig, S.; Gonzalez-Olmos, R.; Balaguer, M.D.; Colprim, J. Continuous acetate production through microbial electrosynthesis from $\mathrm{CO}_{2}$ with microbial mixed culture. J. Chem. Technol. Biotechnol. 2016, 91, 921. [CrossRef]

7. Patil, S.A.; Arends, J.; Vanwonterghem, I.; Van Meerbergen, J.; Guo, K.; Tyson, G.; Rabaey, K. Selective enrichment establishes a stable performing community for microbial electrosynthesis of acetate from $\mathrm{CO}_{2}$. Environ. Sci. Technol. 2015, 49, 8833-8843. [CrossRef] [PubMed]

8. LaBelle, E.V.; Marshall, C.W.; Gilbert, J.A.; May, H.D. Influence of acidic pH on hydrogen and acetate production by an electrosynthetic microbiome. PLOS ONE 2014, 9, e109935. [CrossRef] [PubMed]

9. Srikanth, S.; Singh, D.; Vanbroekhoven, K.; Pant, D.; Kumar, M.; Puri, S.K.; Ramakumar, S.S.V. Electro-biocatalytic conversion of carbon dioxide to alcohols using gas diffusion electrode. Bioresour. Technol. 2018, 265, 45-51. [CrossRef] [PubMed]

10. del Pilar Anzola Rojas, M.; Zaiat, M.; Gonzalez, E.R.; De Wever, H.; Pant, D. Effect of the electric supply interruption on a microbial electrosynthesis system converting inorganic carbon into acetate. Bioresour. Technol. 2018, 266, 203-210. [CrossRef] [PubMed]

11. Huang, C.; Xu, T.; Zhang, Y.; Xue, Y.; Chen, G. Application of electrodialysis to the production of organic acids: State-of-the-art and recent developments. J. Membr. Sci. 2007, 288, 1-12. [CrossRef]

12. Jiang, C.; Chen, H.; Zhang, Y.; Feng, H.; Shehzad, M.A.; Wang, Y.; Xu, T. Complexation Electrodialysis as a general method to simultaneously treat wastewaters with metal and organic matter. Chem. Eng. J. 2018, 348, 952-959. [CrossRef]

13. Hongo, M.; Nomura, Y.; Iwahara, M. Novel method of lactic acid production by electrodialysis fermentation. Appl. Environ. Microb. 1986, 52, 314-319.

14. Xue, S.; Wu, C.; Wu, Y.; Chen, J.; Li, Z. Bipolar membrane electrodialysis for treatment of sodium acetate waste residue. Sep. Purif. Technol. 2015, 154, 193-203. [CrossRef] 
15. Patil, R.; Truong, C.; Genco, J.; Pendse, H.; Van Heiningen, A. Applicability of electrodialysis to the separation of sodium acetate from synthetic alkaline hardwood extract. Tappi J. 2015, 14, 695-708.

16. Kariduraganavar, M.; Nagarale, R.; Kittur, A.; Kulkarni, S. Ion-exchange membranes: Preparative methods for electrodialysis and fuel cell applications. Desalination 2006, 197, 225-246. [CrossRef]

17. Fidaleo, M.; Moresi, M. Electrodialysis applications in the food industry. Adv. Food Nutr. Res. 2006, 51, 265-360. [PubMed]

18. Wan, D.; Liu, H.; Qu, J.; Lei, P. Bio-electrochemical denitrification by a novel proton-exchange membrane electrodialysis system-A batch mode study. J. Chem. Technol. Biotechnol. 2010, 85, 1540-1546. [CrossRef]

19. Mohan, S.V.; Srikanth, S. Enhanced wastewater treatment efficiency through microbially catalyzed oxidation and reduction: Synergistic effect of biocathode microenvironment. Bioresour. Technol. 2011, 102, 10210-10220. [CrossRef] [PubMed]

20. Chen, X.; Liang, P.; Zhang, X.; Huang, X. Bioelectrochemical systems-driven directional ion transport enables low-energy water desalination, pollutant removal, and resource recovery. Bioresour. Technol. 2016, 215, 274-284. [CrossRef] [PubMed]

21. Andersen, S.J.; Hennebel, T.; Gildemyn, S.; Coma, M.; Desloover, J.; Berton, J.; Tsukamoto, J.; Stevens, C.; Rabaey, K. Electrolytic membrane extraction enables production of fine chemicals from biorefinery sidestreams. Environ. Sci. Technol. 2014, 48, 7135-7142. [CrossRef] [PubMed]

22. Długołęcki, P.; Anet, B.; Metz, S.J.; Nijmeijer, K.; Wessling, M. Transport limitations in ion exchange membranes at low salt concentrations. J. Membr. Sci. 2010, 346, 163-171. [CrossRef]

23. Ghasemi, M.; Daud, W.R.W.; Ismail, M.; Rahimnejad, M.; Ismail, A.F.; Leong, J.X.; Miskan, M.; Liew, K.B. Effect of pre-treatment and biofouling of proton exchange membrane on microbial fuel cell performance. Int. J. Hydrogen Energy 2013, 38, 5480-5484. [CrossRef]

24. Choi, M.-J.; Chae, K.-J.; Ajayi, F.F.; Kim, K.-Y.; Yu, H.-W.; Kim, C.-W.; Kim, I.S. Effects of biofouling on ion transport through cation exchange membranes and microbial fuel cell performance. Bioresour. Technol. 2011, 102, 298-303. [CrossRef] [PubMed]

25. Alam, J.; Dass, L.A.; Alhoshan, M.S.; Ghasemi, M.; Mohammad, A.W. Development of polyaniline-modified polysulfone nanocomposite membrane. Appl. Water Sci. 2012, 2, 37-46. [CrossRef]

26. Upadhyayula, V.K.; Gadhamshetty, V. Appreciating the role of carbon nanotube composites in preventing biofouling and promoting biofilms on material surfaces in environmental engineering: A review. Biotechnol. Adv. 2010, 28, 802-816. [CrossRef] [PubMed]

27. Kim, C.; Ainala, S.K.; Oh, Y.-K.; Jeon, B.-H.; Park, S.; Kim, J.R. Metabolic flux change in Klebsiella pneumoniae L17 by anaerobic respiration in microbial fuel cell. Biotechnol. Bioprocess Eng. 2016, 21, 250-260. [CrossRef]

28. Jaime-Ferrer, J.S.; Couallier, E.; Viers, P.; Durand, G.; Rakib, M. Three-compartment bipolar membrane electrodialysis for splitting of sodium formate into formic acid and sodium hydroxide: Role of diffusion of molecular acid. J. Membr. Sci. 2008, 325, 528-536. [CrossRef]

29. Chukwu, U.; Cheryan, M. Electrodialysis of Acetate Fermentation Broths. In Twentieth Symposium on Biotechnology for Fuels and Chemicals; Humana Press: Totowa, NJ, USA, 1999; pp. 485-499.

30. Wei, P.; Xia, A.; Liao, Q.; Sun, C.; Huang, Y.; Fu, Q.; Zhu, X.; Lin, R. Enhancing fermentative hydrogen production with the removal of volatile fatty acids by electrodialysis. Bioresour. Technol. 2018, 263, 437-443. [CrossRef] [PubMed]

31. Zhang, Y.; Pinoy, L.; Meesschaert, B.; Van der Bruggen, B. Separation of small organic ions from salts by ion-exchange membrane in electrodialysis. AIChE J. 2011, 57, 2070-2078. [CrossRef]

32. Kim, J.R.; Cheng, S.; Oh, S.-E.; Logan, B.E. Power generation using different cation, anion, and ultrafiltration membranes in microbial fuel cells. Environ. Sci. Technol. 2007, 41, 1004-1009. [CrossRef] [PubMed]

33. Drews, A. Membrane fouling in membrane bioreactors-Characterisation, contradictions, cause and cures. J. Membr. Sci. 2010, 363, 1-28. [CrossRef]

34. Zhao, Z.; Shi, S.; Cao, H.; Li, Y.; Van der Bruggen, B. Layer-by-layer assembly of anion exchange membrane by electrodeposition of polyelectrolytes for improved antifouling performance. J. Membr. Sci. 2018, 558, 1-8. [CrossRef]

35. Lee, H.-M.; Jeon, B.-Y.; Oh, M.-K. Microbial production of ethanol from acetate by engineered Ralstonia eutropha. Biotechnol. Bioprocess Eng. 2016, 21, 402-407. [CrossRef]

36. López-Garzón, C.S.; Straathof, A.J. Recovery of carboxylic acids produced by fermentation. Biotechnol. Adv. 2014, 32, 873-904. [CrossRef] [PubMed] 
37. Song, Y.E.; Boghani, H.C.; Kim, H.S.; Kim, B.G.; Lee, T.; Jeon, B.-H.; Premier, G.C.; Kim, J.R. Electricity Production by the Application of a Low Voltage DC-DC Boost Converter to a Continuously Operating Flat-Plate Microbial Fuel Cell. Energies 2017, 10, 596. [CrossRef]

38. Song, Y.E.; Boghani, H.C.; Kim, H.S.; Kim, B.G.; Lee, T.; Jeon, B.H.; Premier, G.C.; Kim, J.R. Maximum Power Point Tracking to Increase the Power Production and Treatment Efficiency of a Continuously Operated Flat-Plate Microbial Fuel Cell. Energy Technol. 2016, 4, 1427-1434. [CrossRef]

39. Matemadombo, F.; Puig, S.; Ganigué, R.; Ramírez-García, R.; Batlle-Vilanova, P.; Dolors Balaguer, M.; Colprim, J. Modelling the simultaneous production and separation of acetic acid from $\mathrm{CO}_{2}$ using an anion exchange membrane microbial electrosynthesis system. J. Chem. Technol. Biotechnol. 2017, 92, 1211-1217. [CrossRef]

40. Bajracharya, S.; Van den Burg, B.; Vanbroekhoven, K.; De Wever, H.; Buisman, C.J.; Pant, D.; Strik, D.P. In situ acetate separation in microbial electrosynthesis from $\mathrm{CO}_{2}$ using ion-exchange resin. Electrochim. Acta 2017, 237, 267-275. [CrossRef]

41. Prochaska, K.; Antczak, J.; Regel-Rosocka, M.; Szczygiełda, M. Removal of succinic acid from fermentation broth by multistage process (membrane separation and reactive extraction). Sep. Purif. Technol. 2018, 192, 360-368. [CrossRef]

42. Wang, X.; Wang, Y.; Zhang, X.; Feng, H.; Xu, T. In-situ combination of fermentation and electrodialysis with bipolar membranes for the production of lactic acid: Continuous operation. Bioresour. Technol. 2013, 147, 442-448. [CrossRef] [PubMed]

(C) 2018 by the authors. Licensee MDPI, Basel, Switzerland. This article is an open access article distributed under the terms and conditions of the Creative Commons Attribution (CC BY) license (http:/ / creativecommons.org/licenses/by/4.0/). 